Journal of Nonformal Education and Community Empowerment

Volume 1 (2): 108-119, Desember 2017

Available at http://journal.unnes.ac.id/sju/index.php/jnfc

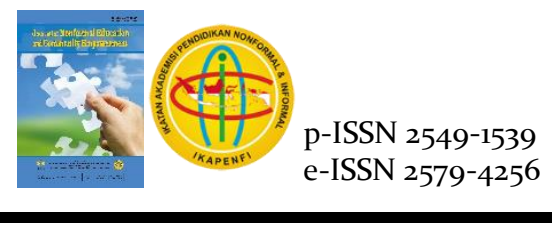

\title{
Peranan Komunitas Harapan dalam Meningkatkan Kemandirian Anak Usia Sekolah di Kawasan Pasar Johar Semarang
}

\author{
Nur Hasanah ${ }^{凶}$, Tri Joko Raharjo, Amin Yusuf \\ Pendidikan Luar Sekolah, Fakultas Illmu Pendidikan, Universitas Negeri Semarang
}

DOI: $10.15294 /$ pls.v1i2.16557

\section{Info Artikel}

Sejarah Artikel:

Diterima Agustus 2017

Disetujui November 2017

Dipublikasikan Desember 2017

\section{Keywords:}

role of the community;

independents of children

\begin{abstract}
Abstrak
Komunitas Harapan memiliki peranan dalam membentuk kemandirian anak. Penelitian ini bertujuan mendeskripsikan peranan komunitas harapan dan kendala dalam meningkatkan kemandirian anak usia sekolah di Kawasan Pasar Johar Semarang. Penelitian ini menggunakan pendekatan deskriptif kualitatif dengan subjek penelitian terdiri dari anak binaan komunitas harapan, penggagas komunitas harapan, pengelola, dan warga masyarakat. Teknik pengumpulan data melalui observasi, wawancara dan dokumentasi. Keabsahan data menggunakan triangulasi sumber, metode dan teori. Analisis data menggunakan model interaktif. Hasil penelitian bahwa peranan komunitas harapan dalam meningkatkan kemandirian anak usia sekolah yang meliputi peranan fasilitatif, peranan edukatif, dan peranan representatif. Adapun kendalanya adalah koordinasi yang masih terbatas antara pengelola Komunitas Harapan dengan orangtua anak binaan.
\end{abstract}

\begin{abstract}
The Komunitas Harapan has a role in shaping the child's independence. This study aims to describe the role of community expectations and constraints in improving the independence of school-aged children in Pasar Johar Market Semarang. This study used a qualitative descriptive approach with the subject of research consisting of the targeted community supporters, initiators of community expectations, managers, and citizens. Data collection techniques through observation, interview, and documentation. The validity of data using triangulation of sources, methods, and theories. Data analysis using interactive model. The result of the research shows that role of the Komunitas Harapan in improving the independence of school-aged children includes facilitative role, educative role, and representative role. The obstacles are the limited coordination between the Komunitas Harapan organizer and the parents of the assisted children.
\end{abstract}

\footnotetext{
Alamat korespondensi:

E-mail: pls113006@gmail.com
} 


\section{PENDAHULUAN}

Anak sebagai tunas, potensi dan generasi penerus cita-cita perjuangan bangsa memiliki peran strategis dalam upaya menjamin kelangsungan eksistensi bangsa dan negara di masa depan. Masa tumbuh kembang anak merupakan masa-masa rawan yang membutuhkan perhatian serius oleh orangtua maupun orang dewasa lainnya. Masa anak merupakan suatu fase yang sangat penting, berharga, yang merupakan masa pembentukan dalam periode kehidupan manusia. Roopnaire \& Johnson (1993) mengungkapkan bahwa dalam fase perkembangan individu, masa anak merupakan masa yang sangat penting dalam tahap pembentukan dan pengembangan pribadi individu di setiap tahap perkembangannya.

Upaya menunjang keberhasilan individu, maka sejak kecil anak perlu menguasai berbagai kemampuan terutama kemampuan sosial emosional yang baik. Menurut Goleman (1995) keberhasilan hidup seseorang lebih ditentukan oleh kemampuan emosionalnya dibanding dengan kemampuan intelektual. Kemampuan sosial emosional merupakan fondasi bagi perkembangan kemampuan anak berinteraksi dengan lingkungannya secara lebih luas. Megawangi (1993) menyatakan bahwasannya faktor penunjang kesuksesan seseorang di antaranya berupa kecerdasan kognitif, sedangkan yang lainnya adalah kematangan sosial emosi. Hildayani dkk. (2007) menyatakan bahwa terdapat empat aspek perkembangan sosial emosi pada anak yang harus dikembangkan, yaitu perkembangan pemahaman diri, hubungan sosial, kemampuan mengatur diri sendiri, dan perilaku sosial. Sejalan dengan pendapat tersebut, Nuraini \& Sujiono (2010) menyatakan bahwa terdapat tiga hal yang harus dibelajarkan pada aspek perkembangan sosial emosi anak di antaranya; rasa percaya terhadap lingkungan luar diri anak, kemandirian dan pengendalian diri, dan mengambil inisiatif serta belajar berperilaku yang dapat diterima oleh kelompok sosial.

Faktor kemandirian merupakan bagian yang wajib diperhatikan dalam kaitannya dengan perkembangan sosial emosi anak. Tidak hanya itu, kemandirian merupakan bagian dari salah satu aspek kepribadian manusia yang tidak dapat berdiri sendiri, artinya bahwa kemandirian terkait dengan aspek kepribadian yang lain dan harus dilatih pada anak-anak sedini mungkin agar tidak menghambat tugastugas perkembangan anak selanjutnya. Masrun dkk. (1986) menyatakan kemandirian adalah suatu sifat yang memungkinkan seseorang bertindak bebas, melakukan sesuatu atas dorongan diri sendiri, mengejar prestasi, penuh keyakinan dan memiliki keinginan untuk mengerjakan sesuatu tanpa bantuan orang lain, mampu mengatasi persoalan yang dihadapi, mampu mengendalikan tindakan, mampu mempengaruhi lingkungan, mempunyai rasa percaya diri terhadap kemampuan yang dimiliki, menghargai keadaan diri dan memperoleh kepuasan atas usaha sendiri.

Kemandirian pada anak sangat diperlukan karena dengan kemandirian, anak bisa menjadi lebih bertanggung jawab dalam memenuhi kebutuhannya. Komala (2015) menerangkan bahwa betapa pentingnya membangun kemandirian anak. Anak-anak yang memiliki kemandirian secara normal akan cenderung lebih positif di masa depannya. Anak yang mandiri cenderung berprestasi karena dalam menyelesaikan tugas-tugasnya anak tidak lagi tergantung pada orang lain, sehingga anak bisa lebih percaya diri. Rasa percaya diri (adequacy) atau self esteem merupakan perasaan dimana anak mempunyai keyakinan tentang dirinya sendiri bahwa ia mempunyai konsep tentang diri sendiri. Perasaan ini dikembangkan dari interaksi dengan orang lain, yakni dari respon orang lain terhadap dirinya.

Kemandirian tercermin dari cara berpikir dan bertindak, mampu mengambil keputusan, mengarahkan dan mengembangkan diri, serta menyesuaikan diri secara konstruktif dengan norma yang berlaku di lingkungannya (Yusuf, 2007: 130). Hastuti \& Ilyas (2017) menyatakan bahwa kemandirian juga berkenaan dengan tugas dan keterampilan bagaimana mengerjakan sesuatu, bagaimana mencapai sesuatu atau bagaimana mengelola sesuatu, serta kemampuan untuk memikirkan dan melakukan 
sesuatu dengan pikiran sendiri. Sejalan dengan hal tersebut, Steinberg (1995) membagi kemandirian ke dalam tiga aspek, yang terdiri dari kemandirian emosi (emotional autonomy), kemandirian perilaku (behavioral autonomy), dan kemandirian nilai (values autonomy). Kemandirian emosi yaitu aspek kemandirian yang berhubungan perubahan kedekatan atau keterikatan hubungan emosional individu, terutama sekali dengan orangtua atau orang dewasa lainnya yang banyak melakukan interaksi dengannya. Kemandirian perilaku yaitu suatu kemampuan untuk membuat keputusan-keputusan secara bebas untuk menindaklanjuti. Kemandirian nilai yaitu kemampuan untuk memaknai seperangkat benar-salah, baik-buruk apa yang berguna dan sia-sia bagi dirinya sendiri.

Pencapaian kemandirian individu tidak bisa terlepas dari faktor-faktor yang membentuknya. Ada beberapa faktor yang dapat mempengaruhi kemandirian seorang anak, seperti lingkungan, pola asuh, pendidikan, interaksi sosial dan intelegensi (Santrock, 2003). Soetjiningsih (1995) dan Mu'tadin (2002) lebih memerinci faktor-faktor tersebut menjadi dua bagian yaitu faktor internal dan faktor eksternal. Faktor internal merupakan faktor yang terdapat dalam diri anak itu sendiri yang meliputi emosi dan intelektual, sedangkan faktor eksternal merupakan hal-hal yang datang dari luar diri anak, yang meliputi lingkungan, karakteristik sosial, stimulasi, pola asuh, cinta dan kasih sayang, kualitas interaksi antara anak dan orangtua, dan pendidikan orangtua.

Jelas bahwa untuk mendapatkan hasil pengembangan kemandirian anak yang optimal, diperlukan adanya kerja sama yang baik antar komponen lingkungan sosial anak. Lingkungan sosial merupakan lingkungan dimana terjadinya interaksi dalam melakukan sesuatu antar sesama dalam lingkungan dimana individu tersebut berada. Lingkungan sosial terdiri atas keluarga, sekolah dan masyarakat. Keluarga merupakan tempat sosialisasi pertama bagi anak, nilai-nilai dan peran-peran sosial pertamakali didapatkan anak di dalam keluarga, sehingga dari sana keluarga memiliki fungsi untuk membentuk kepribadian individu (Martono, 2014). Tidak hanya itu, lingkungan sekolah dan masyarakat juga seyogyanya memiliki peranan lebih dalam membentuk kepribadian anak terutama dalam hal kemandirian. Terlebih jika keluarga tidak mampu melaksanakan fungsi-fungsi dan peranannya dengan baik. Peranan yang dimaksud dalam hal ini adalah yang berisikan tentang aspek dinamis dari kedudukan, perangkat hak-hak dan kewajiban, perilaku sosial dari pemegang kedudukan, dan bagian dari seseorang yang dimainkan (Soekanto, 2009). Lebih jelasnya, Levinson (Soekanto, 2012) menyatakan bahwa peranan mencakup beberapa hal yang terbagi atas norma-norma yang dihubungkan dengan posisi atau tempat seseorang dalam masyarakat, konsep tentang apa yang dapat dilakukan oleh individu dalam masyarakat sebagai organisasi, dan juga dapat dikatakan sebagai perilaku individu yang penting bagi struktur sosial masyarakat.

Dalam penerapan peranan di masyarakat, sangat dibutuhkan adanya keahlian peranan (role skills) yang mana dapat membuat hubungan interpersonal antar masyarakat berkembang dengan baik. Terlebih jika di dalam suatu masyarakat terdapat seseorang yang bertindak sebagai pengembang masyarakat melalui komunitas (community worker). Maka ia memiliki tugas utama untuk mengembangkan kapasitas pelaku masyarakat, sehingga mampu mengorganisir dan menentukan sendiri upayaupaya yang diperlukan dalam memperbaiki kehidupan usaha mereka (Muslim, 2009). Begitu pula dengan Ife \& Tesoriero (2008) yang menyatakan setidaknya terdapat empat peranan dan keterampilan utama yang harus dimiliki dan dijalankan oleh community worker yakni peranan memfasilitasi (fasilitative roles), peranan mendidik (educational roles), peranan representasi (representational roles), dan peranan teknis (technical roles).

Belakangan ini banyak sekali muncul berbagai kasus yang terjadi akibat kurang terlaksananya fungsi peranan dengan semestinya, baik yang terjadi di lingkungan keluarga maupun masyarakat. Menurut data dari Komisi Perlindungan Anak Indonesia 
(KPAI), selama tahun 2013 terdapat indikasi yang menunjukkan bahwa lingkungan keluarga Indonesia masih cenderung diwarnai oleh sejumlah problematika keluarga yang sangat tidak kondusif terhadap masa depan anak Indonesia. Beragam kasus yang melibatkan keluarga masih belum terselesaikan. Kerentanan keluarga baik dari sisi ekonomi, sosial, kemasyarakatan dan religiusitas keagamaan menjadi faktor dominan terhadap kompleksitas permasalahan anak. Wakil Ketua KPAI, Maria Advianti kepada Harian Terbit, Minggu (14/6/2015) memaparkan bahwa terdapat 5 kasus tertinggi yang melibatkan anak-anak dengan jumlah kasus per bidang dari 2011 hingga April 2015, yaitu anak berhadapan dengan hukum hingga April 2015 tercatat 6006 kasus, pengasuhan 3160 kasus, pendidikan 1764 kasus, kesehatan dan napza 1366 kasus serta pornografi dan cybercrime sebanyak 1032 kasus. Anak berada di jalanan, anak diekploitasi, anak ditelantarkan, anak diperdagangkan, anak terlibat pornografi dan anak berhadapan dengan hukum terjadi karena rapuhnya pondasi keluarga.

Potret fenomena yang ada banyak dijumpai di lingkungan keluarga yang berada dalam lingkungan marjinal, seperti di kawasan pasar yang merupakan kawasan pemukiman kumuh, yang di dalamnya sering dijumpai perilaku-perilaku menyimpang melanggar norma-norma sosial. Perhatian utama pada penghuni permukiman kumuh adalah kerja keras mencari nafkah atau hanya sekedar memenuhi kebutuhan sehari-hari agar tetap bertahan hidup, dan bahkan tidak sedikit warga setempat yang menjadi pengangguran. Sehingga tanggungjawab terhadap disiplin lingkungan, norma sosial dan hukum, kesehatan, solidaritas sosial, tolong menolong, menjadi terabaikan dan kurang diperhatikan. Daerah ini sering dipandang potensial menimbulkan banyak masalah perkotaan, karena dapat merupakan sumber timbulnya berbagai perilaku menyimpang, seperti kejahatan, dan sumber penyakit sosial lainnya (Andika, 2012).

Komunitas Harapan sebagai suatu kelompok sosial yang bergerak dalam bidang sosial pendidikan, memberikan pelayanan pendidikan nonformal kepada anak-anak di kawasan Pasar Johar Semarang. Sebagaimana lingkungan Pasar Johar terkategorikan sebagai lingkungan perkampungan kumuh di Kota Semarang. Komunitas Harapan memiliki perhatian lebih terhadap pembangunan kepribadian warga belajarnya. Komunitas ini berdiri pada tanggal 2 Januari 2013. Latar belakang dibentuknya Komunitas Harapan, berangkat dari keprihatinan Agung Setia Budi (Agung Wong) melihat kondisi anak-anak di sekitar tempat tinggalnya yakni di Kampung Sumeneban RT 03, RW 04, Kelurahan Kauman, Semarang. Kehidupan anak-anak yang tumbuh dan besar di lingkungan yang tidak sepenuhnya kondusif dalam membentuk mental dan kepribadian, menimbulkan kekhawatiran besar akan masa depan mereka. Kondisi lingkungan yang terkenal keras, dan kesibukan para orang tua dalam mencari nafkah untuk memenuhi kebutuhan ekonomi keluarga, membuat orangtua sedikit lupa memberikan perhatian lebih kepada anak-anaknya yang mengakibatkan anak-anak hidup lebih bebas tanpa adanya kontrol dan pengawasan. Hasilnya anak-anak pun sering melakukan tindakan yang kurang terpuji bahkan lepas kontrol karena mereka hidup mencontoh dari orang-orang di sekitar lingkungan mereka yang mayoritas belum bisa memberikan contoh perilaku yang baik (Susetiadi, 2015).

Fakta yang dapat diungkap di lapangan, bahwasannya kondisi anak-anak di kawasan Pasar Johar memang tergolong cukup memperihatinkan. Ada beberapa anak yang kurang mendapatkan perhatian lebih dari orangtuanya sehingga seringkali bersikap berlebihan untuk mendapatkan perhatian dari orang-orang sekitar. Bahkan ada juga yang hingga tidak terawat kondisi fisiknya, sehingga membuat orang lain segan untuk mendekatinya, dan mereka kerap dijadikan sebagai bahan ejekan oleh teman-temannya. Selain itu, ada juga anak yang kerap mendapatkan perilaku kekerasan dari orangtuanya, baik kekerasan secara verbal maupun nonverbal yang 
menyebabkan anak-anak turut melakukan hal yang serupa.

Melalui permasalahan yang ada, Komunitas Harapan hadir memberikan perbaikan untuk lingkungan sekitar, yakni dengan memberikan berbagai kegiatan positif untuk anak-anak. Kegiatan seperti belajar bersama dan juga bermain bersama, yang mana di dalamnya ditanamkan berbagai hal terkait dengan pengetahuan dan sikap. Pada mulanya, kegiatan pembelajaran di Komunitas Harapan diterapkan dalam sistem memberikan kesempatan belajar secara berjenjang yakni kakak kelas memberikan arahan atau membantu adik kelasnya dalam kegiatan bermain dan belajar, sehingga sejak dini anak-anak timbul sikap saling menyayangi dan menghormati. Lambat laun, kegiatan di Komunitas Harapan pada akhirnya mendapatkan bantuan dari beberapa relawan atau yang kerap disebut sebagai "Nekaterzz" yang memberikan berbagai macam pembelajaran seperti mengaji Alquran, pendidikan agama islam, pendidikan budi pekerti, keterampilan, dan pengembangan bakat minat.

Dalam pelaksanaan perannya, Komunitas Harapan membagi kerjanya ke dalam empat divisi yang terdiri atas divisi program, divisi pengembangan sumber daya manusia (PSDM), divisi humas, dan divisi rumah produksi. Selain divisi-divisi tersebut, dalam struktur Komunitas Harapan juga terdapat sekretaris, bendahara, koordinator komunitas dan penggagas, antar satu komponen dengan komponen lainnya saling bersinergi dalam menjalankan perananperanannya untuk mencapai tujuan bersama. Seperti yang terdapat dalam kata "harapan" yang merupakan akronim dari "hari-hari anak bermasa depan". Harapannya, masa depan yang nanti mereka jalani sesuai dengan impian dan cita-cita yang sudah mereka gantungkan sejak masih anak-anak. Harapannya juga, anak-anak yang dididik oleh Komunitas Harapan menjadi anak-anak generasi masa depan yang sukses dan berhasil, bertanggungjawab, menjadi inspirasi bagi orang lain, serta bisa membuat bangga orangtua mereka masing-masing.
Berdasarkan latar belakang yang ada, perlu diungkap peran dari Komunitas Harapan dalam meningkatkan kemandirian anak usia sekolah di kawasan Pasar Johar Semarang. Oleh karenanya, tujuan penelitian ini adalah mendeskripsikan peranan dan berbagai kendala Komunitas Harapan dalam meningkatkan kemandirian anak usia sekolah di kawasan Pasar Johar Semarang.

\section{METODE}

Penelitian ini menggunakan pendekatan deskriptif kualitatif dengan subjek penelitian terdiri dari 3 anak binaan komunitas harapan, 1 penggagas Komunitas Harapan, 2 pengelola, dan 1 warga masyarakat. Penelitian deskriptif kualitatif ini bertujuan mendeskripsikan secara jelas dan terperinci serta memperoleh data yang mendalam dari permasalahan penelitian yaitu terkait bagaimana peranan Komunitas Harapan dalam meningkatkan kemandirian anak usia sekolah di kawasan Pasar Johar Semarang, beserta berbagai kendala yang meliputinya.

Penelitian berada di Kampung Sumeneban RT 03, RW 04, Kelurahan Kauman, Semarang (Kawasan Pasar Johar Semarang). Selain di base camp Komunitas Harapan, penelitian ini juga dilakukan di wilayah sekitar Kampung Sumeneban. Alasan peneliti memilih Komunitas Harapan sebagai lokasi penelitian ialah karena komunitas harapan telah melakukan berbagai program yang memfokuskan pada pengembangan diri anak-anak yang mana hal ini sejalan dengan topik yang akan diungkap dalam penelitian ini. Selain itu, nama Komunitas Harapan juga telah tersohor di berbagai lini di lingkungan sekitar Semarang, berbagai penghargaanpun telah banyak diraihnya.

Fokus penelitian ini yaitu untuk mengetahui bagaimana proses peranan komunitas harapan dalam meningkatkan kemandirian anak usia sekolah di kawasan pasar johar Semarang, yang meliputi: Peranan komunitas meliputi peranan fasilitatif, peranan edukatif, peranan representasi, dan peranan teknis; kemandirian anak usia sekolah meliputi kemandirian emosional, kemandirian sosial, 
kemandirian perilaku, dan kemandirian berpikir; kendala-kendala komunitas harapan dalam mewujudkan peranan dalam meningkatkan kemandirian anak usia sekolah di kawasan Pasar Johar Semarang.

Sumber data penelitian tentang peranan komunitas harapan dalam meningkatkan kemandirian anak usia sekolah di Kawasan Pasar Johar Semarang terbagi menjadi dua, yakni data primer dan data sekunder. Data primer didapatkan melalui penggagas komunitas, pengelola komunitas, warga belajar, dan orangtua/masyarakat, yang dilakukan melalui teknik wawancara secara langsung. Adapun data sekunder yang digunakan berupa buku-buku yang relevan dengan judul penelitian, jurnal dan artikel ilmiah baik dari perpustakaan, internet, dan juga objek-objek di sekitar lokasi penelitian.

Teknik pengumpulan data menggunakan observasi, wawancara, dan dokumentasi. Keabsahan data menggunakan triangulasi sumber dan triangulasi metode. Triangulasi ini digunakan untuk membandingkan dan mengecek derajat kepercayaan suatu informasi yang diperoleh dari informan sesuai dengan pedoman kisi-kisi yang telah disiapkan dalam proses pengumpulan data. Adapun analisis datanya menggunakan model interaktif yaitu pengumpulan data, reduksi data, penyajian data dan penarikan kesimpulan.

\section{HASIL DAN PEMBAHASAN}

\section{Peranan Komunitas Harapan dalam Meningkatkan Kemandirian Anak Usia Sekolah}

Kemandirian merupakan kemampuan untuk mengendalikan dan mengatur pikiran, perasaan dan tindakan sendiri secara bebas serta berusaha sendiri untuk mengatasi perasaan-perasaan malu dan keragu-raguan. Dalam konteks ini, kemandirian menurut Desmita (2011) biasanya ditandai dengan kemampuan menentukan nasib sendiri, kreatif dan inisiatif, mengatur tingkah laku, bertanggungjawab, mampu menahan diri, membuat keputusan sendiri, serta mampu mengatasi masalah tanpa ada hubungan dari orang lain. Kemandirian juga dapat diartikan sebagai suatu kemampuan mengatur diri sendiri dalam rangka melaksanakan kewajiban hidupnya tanpa bergantung dengan orang lain, yang dilakukan dengan penuh tanggung jawab.

Sisi kemandirian individu dapat ditinjau melalui beberapa aspek, baik dari sisi emosional, perilaku dan nilai (Steinberg, 1995). Havinghurst (dalam Mu'tadin, 2002) menambahkan bahwa kemandirian dalam konteks individu memliki aspek yang lebih luas dari sekedar aspek fisik dan perilaku, yakni terdiri atas aspek emosi, sosial, ekonomi, dan intelegensi. Dengan demikian bahwasannya aspek kemandirian anak dapat ditinjau dari segi emosi, sosial, perilaku, dan berpikir.

Perwujudan kemandirian dibutuhkan adanya peranan. Soekanto (2012:212), "peranan (role) merupakan aspek dinamis kedudukan (status)". Berarti bahwa apabila seseorang melaksanakan hak dan kewajibannya sesuai dengan kedudukannya, maka dia telah menjalankan suatu peranan. Peranan lebih banyak mengarah pada fungsi, penyesuaian diri, dan sebagai suatu proses. Sejalan dengan hal tersebut, George \& Boeree (2010) juga menyatakan bahwa peranan kaitannya dengan kompleks pengharapan manusia terhadap caranya individu harus bersikap dan berbuat dalam situasi tertentu berdasarkan status dan fungsi sosialnya. Sementara itu, dalam pengembangan komunitas (community development) menurut Muslim (2009) terdapat seorang community worker yang berlaku sebagai pelaku pengembang masyarakat, yang memiliki tugas utama untuk mengembangkan kapasitas pelaku masyarakat sehingga mampu mengorganisir dan menentukan sendiri upayaupaya yang diperlukan dalam memperbaiki kehidupan usaha mereka. Berbagai peran kerja community worker berdasarkan teori Ife \& Tesoriero (2008), era globalisasi telah dikelompokkan ke dalam empat golongan, yaitu facilitative roles (peranan memfasilitasi), educational roles (peranan mendidik), representative roles (peranan perwakilan) dan technical roles (peranan teknis). 
Sebagaimana fokus penelitian ini adalah peranan komunitas harapan dalam meningkatkan kemandirian anak usia sekolah, peranan yang dimaksud adalah peranan fasilitatif, edukatif, representatif, dan teknis. Peranan fasilitatif terkait dengan kemampuan Komunitas Harapan dalam memfasilitasi kebutuhan anak-anak binaan Komunitas Harapan, baik dalam bentuk pemenuhan kebutuhan materiil, pemenuhan kebutuhan nonmateriil, dan juga pendekatan personal. Pemberian fasilitasi dalam bentuk materiil sejauh ini sudah terlaksana dengan baik, yakni berupa pemberian alat tulis, perlengkapan sholat, buku bacaan, dan kedepannya komunitas harapan juga akan memberikan layanan program beasiswa sekolah kepada anak-anak binaan Komunitas Harapan. Pemberian fasilitasi dalam bentuk materiil memiliki peranan dalam meningkatkan kemandirian perilaku anak, yang mana melalui hal tersebut anak-anak menjadi dapat lebih bertanggungjawab terhadap tugastugasnya atau kewajibannya. Peranan fasilitas tersebut sebagaimana Ife \& Tesoriero (2008), berkaitan dengan stimulasi dan penunjang pengembangan masyarakat, yang terbagi atas semangat sosial, mediasi dan negosiasi, dukungan, membangun konsensus, fasilitasi kelompok, pemanfaatan berbagai keterampilan dan sumberdaya, mengatur (mengorganisasi), dan komunikasi personal.

Terkait pemberian fasilitasi dalam bentuk nonmateriil, Komunitas Harapan melakukannya melalui kegiatan-kegiatan yang menyesuaikan keinginan anak, baik bersifat pelatihan, pembelajaran maupun permainan. Selain hal tersebut, relawan komunitas harapan juga seringkali memberikan layanan sukarela secara fleksibel yang merupakan bentuk perhatian terhadap kondisi anak-anak binaan komunitas harapan, yang mana terdapat beberapa anak yang kurang mendapatkan perhatian dari orangtuanya sehingga kondisi fisiknya kurang terawat dengan baik. Adapun bentuk fasilitasi tersebut berupa melakukan potong rambut, memandikan dan juga mendandani mereka agar terlihat lebih rapi dan bersih.
Pemberian fasilitasi secara nonmateriil memiliki peranan dalam membentuk kemandirian emosi, sosial, perilaku, dan berpikir anak. Melalui program kegiatan yang berfokus pada perkembangan emosi anak, membuat anak lebih terlatih dalam mengontrol emosinya. Kaitannya dengan aspek kemandirian sosial, anak-anak diperkenalkan dengan kondisi lingkungan setempat yang seringkali berubahubah sehingga menuntutnya untuk dapat beradaptasi dengan lingkungan setempat, anakanak juga dihadapkan dengan banyaknya orangorang yang berkegiatan di dalamnya sehingga menuntutnya untuk berinteraksi dengan orangorang sekitar, terutama orang-orang yang baru. Dari segi kemandirian perilaku, bahwasannya kepercayaan diri anak telah terlatih karena anakanak telah terbiasa tampil melalui berbagai kegiatan yang diselenggarakan. Berbeda dengan ketiga aspek kemandirian emosi, sosial, dan perilaku yang mana telah menunjukkan peningkatan dalam diri anak, namun pada aspek kemandirian berpikir masih belum begitu tampak hasilnya, karena anak-anak belum cukup mampu berpikir memecahkan masalahnya sendiri ketika dibenturkan pada permasalahan-permasalahan dalam berkegiatan, anak-anak juga belum cukup mampu mengambil keputusan secara mandiri ketika dihadapkan pada berbagai pilihan ketika sedang berkegiatan.

Sebelum melakukan peranan fasilitasi, para relawan komunitas harapan terlebih dulu mencari tahu tentang kebutuhan maupun keinginan anak, yakni dengan cara mengamati, sehingga tidak langsung menanyakan kepada anak-anak tentang apa yang mereka inginkan atau butuhkan. Selain mengamati, Komunitas Harapan juga melaksanakan pendekatan secara personal untuk lebih mengetahui keinginan dan kebutuhan anak-anak. Dalam melakukan pendekatan personal, komunitas harapan senantiasa menjalin komunikasi dan koordinasi kepada anak-anak binaan Komunitas Harapan. Pendekatan personal memiliki andil dalam membangun sisi kemandirian emosi, sosial, perilaku, dan berpikir anak. Melalui pendekatan personal anak-anak mendapatkan masukan dan 
perlakuan, sehingga ia menjadi lebih terbuka terhadap permasalahannya, dan setelah itu membuat perjanjian agar tidak mengulangi hal serupa, sehingga luapan emosi anak menjadi lebih terkontrol. Dari segi kemandirian sosial, dalam melakukan pendekatan personal anakanak diajarkan dan dicontohkan tentang bagaimana beradaptasi dengan lingkungan setempat, maupun berinteraksi dengan orangorang sekitar. Melalui pendekatan personal, anak-anak juga menjadi lebih terbuka dan lebih mudah diarahkan sehingga ia menjadi lebih patuh terhadap perintah kebaikan. Berbeda dengan ketiga aspek kemandirian emosi, sosial, dan perilaku yang mana telah menunjukkan peningkatan dalam diri anak, namun pada aspek kemandirian berpikir masih belum begitu tampak hasilnya. Karena melalui pendekatan personal yang berlebihan, anak menjadi terlalu bergantung terhadap pemikiran dan perlakuan orang lain sehingga anak belum cukup mampu mengatasi permasalahannya sendiri, anak juga menjadi terlalu bergantung terhadap masukanmasukan dari orang lain, ia masih harus sering diberikan arahan sehingga anak belum cukup mampu mengambil keputusan secara mandiri.

Peranan edukatif, Komunitas Harapan yaitu adanya aktivitas pendidikan. Pendidikan adalah salah satu aspek terpenting dari peran seorang pekerja masyarakat, dengan begitu keterampilan dalam mendidik adalah sangat penting. Adapun peran mendidik menurut Ife \& Tesoriero (2008) terbagi menjadi peningkatan kesadaran, memberikan informasi, konfrontasi, pelatihan. Peranan edukatif yang dimaksud dalam penelitian ini adalah pemberian program pembelajaran maupun pelatihan kepada anakanak binaan Komunitas Harapan yang bertujuan untuk mengedukasi anak-anak agar semakin bertambah pengetahuan dan keterampilannya. Sejauh ini, pelaksanaan program pembelajaran dan pelatihan telah berjalan dengan baik, yang telah diatur sesuai jadwal pengajaran rutin tiap minggunya. Dalam pelaksanaan kegiatan pembelajaran rutinan, lebih menekankan pada pemberian kegiatan pembelajaran secara nonformal, karena hal tersebut dinilai lebih efektif, lebih mudah diaplikasikan dan lebih tepat sasaran. Berdasarkan hal tersebut pada akhirnya saat ini kegiatannya lebih difokuskan pada pengembangan minat dan bakat anak, yang dilakukan dalam bentuk pelatihan. Selain itu, dalam penyusunan program pembelajaran, komunitas harapan juga sudah tidak lagi menggunakan kurikulum atau silabus, sehingga kegiatan yang dilakukan pun mengalir begitu saja, namun tetap terprogram, yang mana pelaksanaannya lebih berpusat pada keinginan anak. Hal tersebut dilakukan agar program pembelajaran dan pelatihan tersebut dapat diterima dengan baik oleh anak.

Pelaksanaan peranan edukatif terkait penyelenggaraan program pembelajaran dan pelatihan, memberikan andil terhadap peningkatan kemandirian emosi, sosial, perilaku anak. Melalui penyelenggaraan program pembelajaran dan pelatihan yang berfokus pada perkembangan emosi anak, membuat anak lebih terlatih dalam mengontrol emosinya. Selain itu, dalam penyelenggaraan berbagai program pembelajaran dan pelatihan, anak-anak menjadi terlatih untuk beradaptasi dengan kondisi dan situasi lingkungan setempat, dan anak-anak juga menjadi terlatih untuk berinteraksi dengan orang lain.

Kaitannya dengan kemandirian perilaku, dalam penyelenggaraan program pembelajaran dan pelatihan, anak-anak seringkali diberikan tugas-tugas sehingga melatihnya untuk lebih dapat bertanggungjawab terhadap tugastugasnya dan anak-anak juga menjadi terbiasa melakukan berbagai kegiatan, sehingga melatih sisi kepercayaan dirinya. Berbeda dengan aspek kemandirian emosi, sosial, dan perilaku anak yang mana telah memberikan hasil terhadap peningkatan kemandirian anak, namun pada aspek berpikir anak belum cukup mampu menggunakan pikirannya sendiri dalam memecahkan masalah maupun mengambil keputusan, masih diperlukan adanya pendampingan dari para relawan Komunitas Harapan maupun orang dewasa ketika pelaksanaan program pembelajaran dan pelatihan. 
Pemberian pemahaman tentang pendidikan karakter atau kepribadian juga seringkali dilakukan relawan Komunitas Harapan dengan menyisipkannya pada kegiatan pembelajaran atau pelatihan. Melalui pemberian pemahaman terkait pendidikan karakter dan kepribadian, anak-anak mendapatkan masukan agar senantiasa dapat mengontrol emosinya. Dari sisi kemandirian sosial, hal tersebut juga dapat membuat anak menjadi lebih mengerti tentang bagaimana beradaptasi dengan kondisi dan situasi lingkungan setempat maupun bagaimana berinteraksi dengan orang lain. Melalui pemberian pemahaman terkait pendidikan karakter atau kepribadian, anakanak menjadi lebih terarah sehingga ia menjadi lebih patuh terhadap perintah kebaikan. Pemberian pemahaman tentang pendidikan karakter atau kepribadian dalam kaitannya dengan meningkatkan kemandirian berpikir anak, dilakukan dengan mengarahkan anak agar mampu menyelesaikan permasalahannya sendiri, maupun mengambil keputusan secara mandiri, namun anak-anak belum cukup mampu melakukannya secara mandiri.

Peranan edukatif dalam meningkatkan kemandirian anak tidak hanya dilakukan secara teoritis namun juga secara praktis, yakni dengan memberikan contoh keteladanan yang baik dari para relawan maupun orang dewasa sehingga anak-anak mampu terstimulus untuk melakukan hal serupa. Melalui pemberian keteladanan yang baik tentang pengontrolan emosi, membuat anak-anak dapat mencontoh secara langsung tentang bagaimana mengontrol emosi. Selain itu, pemberian keteladanan yang baik tentang bagaimana beradaptasi dengan kondisi dan situasi lingkungan maupun dengan orang lain, membuat anak menjadi mengerti tentang bagaimana seharusnya ia menempatkan diri. Pemberian keteladanan yang dapat dijadikan sebagai figur contoh dalam berbuat kebaikan membuat anak menjadi lebih patuh terhadap perintah kebaikan.

Peranan representatif Komunitas Harapan ditunjukkan adanya berbagai peran seorang pekerja masyarakat dalam berinteraksi dengan pihak luar demi kepentingan, atau agar bermanfaat bagi masyarakat. Adapun peranan representasi yang dilakukan kepada pihak eksternal, yakni sifatnya lebih kepada menjalin kerjasama, baik berupa pelaksanaan kegiatan, maupun pemberian bantuan. Adapun pihakpihak yang telah bekerjasama dengan komunitas harapan yakni berasal dari komunitas, universitas, yayasan, instansi, maupun pemerintahan. Melalui kerjasama dengan pihak luar, yang mana seringkali dihadapkan pada situasi dan kondisi maupun orang-orang yang berbeda-beda sehingga membuat anak-anak terlatih untuk beradaptasi dan berinteraksi dengan lingkungan sekitar.

Melalui kegiatan kerjasama dengan pihak luar, baik berupa penyelenggaraan kegiatan maupun pemberian bantuan, yang ditujukan kepada anak-anak sehingga anak-anak memiliki amanah agar mampu bertanggungjawab terhadap apa yang orang lain berikan. Ketika berlangsung kegiatan yang mana berisikan orang-orang maupun kondisi yang baru sehingga seringkali anak dihadapkan pada beberapa masalah, akhirnya anak-anak kerap diarahkan untuk berpikir memecahkan permasalahannya sendiri maupun mengambil keputusannya secara mandiri, namun sejauh ini anak-anak belum cukup mampu mengatasinya secara mandiri. Berbagai peran representasi yang ada, menurut Ife \& Tesoriero (2008) antara lain memperoleh sumberdaya, advokasi, menggunakan media, humas dan presentasi publik, jaringan kerja, berbagi pengetahuan dan pengalaman.

Pembentukan kepribadian anak, Komunitas Harapan menjalin hubungan kerjasama dengan orangtua anak-anak binaan, yang mana sifatnya lebih kepada mengedukasi para orangtua agar juga dapat mendukung kegiatan pengembangan anak-anak, dan juga terkait dengan bagaimana orangtua dalam mendidik anaknya di rumah. Namun program ini belum terlaksana dengan baik, karena sejauh ini bentuk koordinasi antara pihak Komunitas Harapan dengan orangtua anak-anak binaan yakni hanya dilakukan melalui kumpulan warga dengan memberikan informasi tentang kegiatan dan juga mengajak para orangtua untuk ikut 
serta mendampingi anak-anak ketika sedang melaksanakan kegiatan di luar. Namun sejauh ini hal tersebut masih belum mendapatkan respon yang baik dari para orangtua. Para orangtua masih cenderung fokus pada kesibukannya masing-masing. Melalui komunikasi dan kerjasama dengan orangtua, diharapkan dapat lebih mengontrol kondisi kepribadian anak, terutama dari segi emosionalnya.

Beberapa aspek pengembangan masyarakat senantiasa melibatkan aplikasi berbagai keterampilan teknis untuk membantu proses pengembangan masyarakat. Peranan teknis yang dimaksud dalam hal ini yakni tentang bagaimana Komunitas Harapan dalam melakukan pengelolaan baik dari segi kegiatan maupun organisasi. Dalam pengelolaan program kegiatannya, baik yang bersifat pemberian materi, sosialisasi, pelatihan, permainan, perlombaan, penampilan maupun kunjungan, sejauh ini belum cukup terkelola dengan baik namun senantiasa terdapat perkembangan dari waktu ke waktu ke arah yang lebih baik. Adanya program kegiatan tersebut memiliki tujuan sebagai bekal bagi anak-anak untuk menambah pengetahuan, keterampilan, dan pengalamannya sehingga menjadikan anak menjadi pribadi yang lebih mandiri. Adapun yang menjadi bagian dalam peranan teknis menurut Ife \& Tesoriero (2008) adalah penelitian, penggunaan komputer, presentasi verbal dan tertulis, manajemen, pengaturan keuangan.

Komunitas Harapan dalam mengelola organisasinya, telah membentuk struktur organisasi yang terdiri atas berbagai divisi. Devisi tersebut meliputi divisi pengembangan SDM, divisi program, divisi hubungan masyarakat, dan divisi rumah produksi. Selain itu juga terdapat pengurus harian seperti koordinator, sekretaris, dan juga bendahara. Adanya struktur yang berisikan beberapa divisi dan pengurus harian seperti di atas, memberikan kemudahan bagi komunitas harapan dalam melaksanakan peranan-peranannya, terutama dalam pengelolaan kegiatan. Meskipun program kegiatan maupun organisasinya belum sepenuhnya terkelola dengan baik, namun senantiasa melakukan perbaikan yang dapat dilihat berdasarkan perkembangan dari waktu ke waktu yang semakin membaik.

Pelaksanaan peranan teknis selain melakukan pengelolaan kegiatan dan organisasi, Komunitas Harapan juga melakukan pendataan kepada pengelola maupun anak-anak binaan. Pendataan terhadap anak-anak binaan dilakukan dengan menanyakan langsung kepada anak-anak tersebut dan juga kepada orangtuanya, adapun keperluan pendataan tersebut yakni agar pengelola dapat lebih mengerti tentang kondisi anak, sehingga anakanak dapat tertangani dengan semestinya, dan juga dapat dijadikan rujukan sebagai pertimbangan untuk melibatkan anak-anak dalam berkegiatan. Data tersebut juga kelak akan digunakan sebagai rujukan untuk pemberian dana beasiswa kepada anak-anak yang membutuhkan dan memenuhi kriteria.

\section{Kendala dalam meningkatkan kemandirian anak usia sekolah}

Selama empat tahun Komunitas Harapan berjuang mewujudkan perananannya, terutama dalam hal meningkatkan kemandirian anak pastinya menjumpai beberapa kendala, yang berasal dari segi internal maupun eksternal. Pihak pengelola seringkali mengeluhkan terkait kondisi relawan tetap (nekaterzz) yang tidak menentu, yang kehadirannya tidak selalu stabil, sehingga hal tersebut juga berdampak pada kegiatan-kegiatan yang dilakukan, baik kegiatan pembelajaran rutin maupun kegiatan di luar pembelajaran. Pada kegiatan pembelajaran rutin, belakangan ini kehadiran nekaterzz tidak begitu menjadi masalah karena masih dapat dibantu oleh relawan sementara yang tidak terikat dari struktur komunitas harapan, seperti yang berasal dari sekolah, kampus, orginisasi, komunitas, dan lain sebagainya, yang secara berkala mengisi kegiatan pembelajaran maupun pelatihan. Melalui hal tersebut, pihak pengelola akhirnya hanya bertugas mengawasi jalannya kegiatan tanpa harus terlalu turut serta dalam pelaksanaan kegiatan tersebut. Terkait dengan 
pelaksanaan program kegiatan yang lain, para pengelola masih terus berusaha untuk menjalankan program tersebut dengan sebaikbaiknya meskipun seringkali terkendala sumberdaya manusianya

Terkait proses pembentukan kemandirian anak, pengelola menjumpai adanya kendala. Terlebih dalam hal membentuk kemandirian anak diperlukan adanya kerjasama yang baik antar semua pihak yang berada di sekitar kehidupan anak, seperti guru, orangtua maupun masyarakat sekitar. Komunitas Harapan yang merupakan bagian dari masyarakat setempat, merasa bahwa sejauh ini kurang adanya kerjasama yang baik dengan orangtua anak-anak binaan. Hal tersebut terlihat melalui respon orangtua yang terkadang tidak sepenuhnya mendukung anaknya untuk mengikuti kegiatan, dan juga keadaan orangtua yang masih terlalu sibuk mengurusi pekerjaan sehingga terkadang kurang memperhatikan kondisi anaknya.

Sejauh ini, proses koordinasi antara pihak Komunitas Harapan dengan para orangtua hanya dilakukan melalui perkumpulan arisan warga, yang mana sifatnya hanya sebatas menghimbau agar orangtua turut mendukung kegiatan anak-anak, dan mengajak para orangtua untuk ikut serta menemani anaknya ketika berkegiatan di luar. Namun oleh karena kesibukan masing-masing orangtua, pada akhirnya hal tersebut tidak begitu berjalan dengan baik. Pihak pengelola juga senantiasa memikirkan cara untuk mengedukasi para orangtua agar mereka mengerti tentang cara mengasuh anak dengan baik. Terutama menyesuaikan dengan kondisi anak-anak saat ini, sehingga pembentukan kepribadian anak dapat berlangsung dengan optimal.

\section{SIMPULAN}

Terdapat empat peranan yang dilakukan Komunitas Harapan yang terbagi atas peranan fasilitatif, peranan edukatif, peranan representatif, dan peranan teknis. Empat peranan tersebut yang memberikan andil terhadap peningkatan kemandirian anak yakni hanya peranan fasilitatif, edukatif, dan representatif. Sementara peranan teknis sama sekali tidak memiliki andil dalam memandirikan anak, karena peranan teknis hanya mengarah kepada hal-hal yang bersifat pengelolaan. Adapun kemandirian anak yang terbentuk melalui proses peranan tersebut meliputi empat aspek kemandirian yakni kemandirian emosi, sosial, perilaku, dan berpikir. Kendala yang dirasakan dalam membentuk kemandirian anak yakni terletak pada koordinasi dan kerjasama antara pihak pengelola dengan orangtua anakanak binaan dan masyarakat sekitar untuk turut bersama-sama berjuang meningkatkan kemandirian anak.

Para pengelola dapat lebih memaksimalkan potensi yang dimilikinya melalui pemberian tugas-tugas yang sesuai, dan lebih mampu bertanggungjawab terhadap tugastugasnya. Diperlukan adanya pendekatan lebih intensif dari pihak Komunitas Harapan kepada orangtua anak-anak binaan, agar senantiasa terjalin komunikasi dan koordinasi yang baik antar keduanya, sehingga dapat lebih mengoptimalkam tahap perkembangan anak terutama dari segi kemandiriannya.

\section{DAFTAR PUSTAKA}

Andika, M. (2012). Permukiman kumuh di perkotaan dan permasalahannya.

George, C., \& Boeree, M. (2010). Elizabeth english: An inspirational leader. World Council of Enterostomal Therapists Journal, 30(4), 16.

Goleman, D. (1995). Emotional intelligence. New York: Bantam Dell.

Hastuti, S. D., \& Ilyas, I. (2017). Strategi pembelajaran pelatihan menjahit sebagai upaya meningkatkan kemandirian anak tunagrahita di sekolah luar biasa (SLB) dharma anak bangsa klaten. Journal of Nonformal Education, 3(1), 72-79.

Hildayani, R., Sugianto, M., Tarigan, R., Handayani, E., Pudjiati, R., \& Kouri, A. M. (2007). Psikologi perkembangan anak. Jakarta: Universitas Terbuka.

Ife, J., \& Tesoriero, F. (2008). Community development: Alternatif pengembangan masyarakat di era globalisasi. (M. Sastrawan, Ed.). Yogyakarta: Pustaka Pelajar.

Komala, K. (2015). Mengenal dan mengembangkan kemandirian anak usia dini melalui pola asuh orangtua dan guru. 
Tunas Siliwangi, 1(1), 31-45.

Martono, N. (2014). Sosiologi perubahan sosial: Perspektif klasik, modern, postmodern, dan poskolonial. Jakarta: Rajawali Press.

Masrun, M., Martono, M., Haryanto, H., Harjito, P., Utami, M. S., Bawani, N. A., Aritonang, L., \& Sutjipto, H. (1986). Studi mengenai kemandirian pada penduduk di tiga suku bangsa (jawa, batak, bugis). Yogyakarta.

Megawangi, R. (1993). Keluarga dan peningkatan kualitas sumber daya manusia dalam rangka menyongsong abad 21. Bogor: Fakultas Pertanian, Institut Pertanian Bogor dan BKKBN.

Mu'tadin, Z. (2002). Pengantar pendidikan dan ilmu kesehatan. Yogyakarta: Andi Offset.

Muslim, A. (2009). Metodologi Pengembangan Masyarakat. Yogyakarta: Teras Kompleks.

Nuraini, Y., \& Sujiono, B. (2010). Bermain kreatif berbasis kecerdasan jamak. Jakarta: Indeks. Roopnaire, J. L., \& Johnson, J. E. (1993). Approaches to early childhood education (2nd ed.). New York: Merril.

Santrock, J. W. (2003). Adolescence: Perkembangan remaja. (S. B. A. \& S. Saragih, Ed.). Jakarta: Erlangga.

Soekanto, S. (2009). Sosiologi suatu pengantar. Jakarta: Rajawali Press.

Soekanto, S. (2012). Sosiologi suatu pengantar. Jakarta: Rajawali Press.

Soetjiningsih, S. (1995). Tumbuh kembang anak. Jakarta: EGC.

Steinberg, L. (1995). Adolescent. San Francisco: McGraw Hill Book Company Inc.

Susetiadi, D. (2015). Komunitas harapan lahir kembali.

Yusuf, S. (2007). Psikologi perkembangan anak dan remaja. Bandung: Remaja Rosdakarya. 